\title{
A VÁLSÁG HATÁSAI A MAGYAR KIS- ÉS KÖZÉPVÁLLALATI SZEKTORBAN
}

A szerzók 2009-ben és 2010-ben vizsgálták, hogy a hazai vállalatok milyen veszteségeket szenvedtek, mit tettek ellene, és milyen várakozásokkal tekintenek elôre. Felméréseik fókusza Gyoór és környéke volt. 2009ben a válság elsố pusztító szakaszát regisztrálhatták, az elốrejelzések is pesszimisták voltak. 2010-ben megállapították, hogy a várakozások beigazolódtak, a válság valóban mélynek bizonyult. A cikk értékelō részében az egyes vállalatok helyzetét, intézkedéseiket a válság által meghatározott átlagos mintázathoz képest határozták meg, nyertesnek ítélve azt a vállalatot, amelyik ennél könnyebben, vesztesnek pedig azt, amelyik nehezebben viselte el eddig a krízist.

Kulcsszavak: válság, kis- és középvállalatok, változás mintázatai

Az 1990-es évektól számos kisebb-nagyobb válság söpört végig a világgazdaságon: a skandináv bankválságon keresztül az elsősorban a feltörekvő piacokat érintő pénzügyi válságokon (Mexikó, Oroszország, ázsiai válság, Törökország, Argentína) át a 2000-es évek dot.com válságáig (Király et al., 2008).

A 2008-as válságnak is voltak elôjelei, aztán jöttek a kedvezôtlen fejlemények, majd elérkeztek a vállalkozókhoz a kétségtelen bizonyítékok. A közvetlen hatások elértek mindenkit, a pénzvilágot, a reálgazdaságot, befektetôket és adósokat, szervezeteket és személyeket, gazdagokat és szegényeket egyaránt.

A válság okainak megértése szempontjából két megközelítés érdemel említést: az egyik a pénzpiacok alulszabályozottságával, azaz szabályozási kényszerekkel foglalkozik, a másik megközelítés pedig éppen a pénzpiaci anomáliákkal, elsôsorban az információs aszimmetriákkal (Krugman, 2000), valamint a piaci szereplő́k irracionális, fundamentumokat és belső értékeket figyelmen kívül hagyó viselkedésével magyarázza a válságot (Barberis - Thaler, 2003).

Magyarország helyzete meglehetôsen ambivalens a válság kapcsán: az egyik oldalról Magyarországon nem voltak jelen azok a „,kreatív” subprime hitelból származtatott pénzügyi termékek, amelyek a válság közvetlen kirobbanását okozták, s ezáltal a hazai bankrendszer stabilitása nem került azonnali veszélybe (Losoncz, 2008), ugyanakkor a 2000-es évek első felének költe- kezô gazdaságpolitikája miatti korrekciós, egyensúlyteremtô lépések a magyar gazdaságot legyengült állapotban találták. A reálgazdasági hatások tehát mélyek és hosszan hatók (Losoncz, 2009; 2009a).

Különösen érdekes a kis- és középvállalati szektor helyzetének változása. A 2000-es évek első felében a kkv-szektor múködésének általános gazdasági feltételei ugyanis inkább javultak, és jelentôsen bôvült a külsô pénzügyi forrásokhoz, hitelhez jutás lehetősége is (kkv-k helyzete, 2007). Az Európai Unióhoz való csatlakozás nyújtotta új lehetőségeket a hazai kkv-k jelentôs része nem tudta kihasználni, éppen az ellenkezôje történt: a külföldi vállalatok és az import által gerjesztett nyomás növelte a versenyt, és megnehezítette a cégek további fejlődését. Az egyensúlyteremtô intézkedések első kárvallottjai is a kkv-k köréból kerültek ki. A csökkenő kereslet miatt megroggyant magyar kisvállalatokat mélyütésként érte a 2008-ban kiszélesedő pénzügyi válság. A fokozódó lánctartozás okozta likviditási problémák, a drasztikusan visszaeső és szigorodó hitelfelvételi lehetôségek és a pénzpiaci nehézségek tovább mélyítették a szektor válságát (Gyorsjelentés Magyar gazdaság, 2008/IV és 2009/4.).

Az eddigi kutatásokból már ismert, hogy a kis- és közepes vállalatok különösen érzékenyek a külsố környezet hirtelen és drasztikus változásaira, ezek ugyanis megváltoztatják a szereplői kör számára megválaszolandó problémákat, s ezáltal a környezeti szabályrendszert 
(Tushman - Romanelli, 1985; Wright - Filatotchev képtelenek a megváltozott környezetben kiigazítan vagy akár gyökeresen megváltoztatni üzleti stratégiájukat, alulmaradnak a versenyben, $\mathrm{s}$ véglegesen kiszorulnak a piacról (Fischer - Lee - Johns, 2004). A válságban azon vállalatok kitettsége a legnagyobb, amelyek olya gazdaságpolitikai környezetben múködnek, amely nem képez megfeleló intézményi „biztonsági hálót” a gazdaintézményi rendszeren túl a vállalatok szervezeti, ir

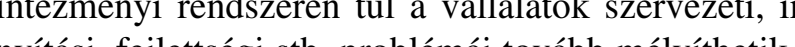
esetleges összeomlásból adódó válságot.

2009-ben azért kezdtük meg a válság kkv-szektorra gyakorolt hatásának vizsgálatát, mert az ismert elemzéseket elsősorban fejlett gazdasági környezetben végezték el. Ezek eredményei ugyanakkor nem szo gálhatnak Magyarországon megfelelố tanulságga, hiszen a fejlödô piacok kkv-szektora környezeti vállalatkarakterisztikai okok miatt mutat eltérést a fe lett országokétól (Hoskisson - Eden - Lau - Wrigh 2000; Wright et al., 2005).

Közismert, hogy a sikerról könnyebb információkat szerezni, mint a kudarcról: amikor jól mennek a dolgok, a vállalkozáskutató készségesen nyilatkozó válla bb, az elzárkókeztetésekre alkamas nagyobb mennyiségú adat beszerzése, az interju ytelen vállalkozás.

A 2009-ben a reálgazdaságra zúdult válság fejleményei mégis arra ösztönöztek, hogy ebben a kudarcca övezett korszakban meg kell próbálkozni a vizsgálattal, az elemzéssel. A válság kezdeti hatásai ekkor már kézzelfoghatóak, a további tendenciák pedig elörebecsülhető́k, illetve a válság lefolyásával kapcsolatos várakozások rögzíthetốk voltak. Az első, a válság hatásait méró kutatási eredmények is megjelentek (Szonda és a Corvinus Egyetem felmérése a Fogyasztói Bizaes a Cor 2009, GKI-és Ecostat-felmérések). Tága teruletre terou Unió rések sem mutattak mást. a realgazdasági visszaesés Climate Index mut

A lehetséges kilábalásról is jelentek meg javaslatok. Két példa: Kiút a válságból. Export recesszió idején, Petrik Ritától a Business Provider Group honlapján címen a Deloitte könyvvizsgálói üzletága készített egy szempontrendszert. Javaslatuk: a vállalatok ez alapján Hoskisson - Peng, 2005). Azok a vállalatok, melye sági szereplốk számára (Sawyerr, 1993). Az eléotele kozókkal találkozik (Rab - Szabó, 2001; Rab - Szabó, kozók . A kalkazc kutás - Szabó, 2001; Rab - Szabó, Ipsos Válságmonitor, Publicus Research, GfK Hungária

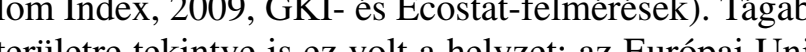
kis- es kozepvall ez volt a helyze az Eutkozó felmémindenüt nagyon jelentôs, ahogy azt a SME Business (Petrik, 2009), illetve Védekezés a válság hatásai ellen

vizsgálják felül múködésüket, illetve a vizsgálat alapzanak a megváltozott körülményekhez igazodó döntéseket.

\section{A felmérések módszere}

Felméréseink 2009 és 2010 tavaszán történtek. A tervezésnél kiderült, hogy a válságjelenségek vizsgálata nem kíván bonyolult módszertant. A vállalati teljesítmény visszaesése néhány tényadattal megragadható, a jövớre vonatkozó várakozások ugyanezeknek az adatoknak az előrebecslésével megismetón. Többféle ké kérdorve alón teszeres kérdóív viszonylag egyszeru let, a kérdezés nem vett igénybe egy órát sem. Ez akkor megfelelt a gyors közlésre voatkozó kutatói ambíciónak is (Szabó, 2009).

A 2009-es kérdő́ív három fố részboól állt. Az elsố rész kérdései a válsággal kapcsolatosak, a második részé a válság miatti azonnali és rövid távú intézkedésekre irányultak, a harmadik részben a vállalat alapadatait kérdeztük meg.

A kérdőív témái a következók voltak:

Mikor észlelte a válság elsó́ jeleit?

Melyek voltak a válság elsó jelei?

Mekkora visszaesés jellemzó az iparágban?

Mekkora volt a forgalom-visszaesés a cégnél a megelózó évekhez képest?

Becslése szerint mikor fordul meg a csökkenó tendencia (cégnél, iparágban)?

Becslése szerint mikor éri el a forgalom a 2008. évi szintet?

második rész kérdései:

Milyen azonnali intézkedéseket tett a cég.

Milyen intézkedésekre kerülhet sor 2009 elsố félévében?

Milyen intézkedésekre kerülhet sor 2009 második félévében?

Milyen intézkedésekre kerülhet sor 2010-ben?

harmadik rész kérdései:

Tevékenység

o termék/szolgáltatás

Foglalkoztatottak száma

ellemzó nettó forgalom az elmúlt években

ellemzó nyereség a nettó forgalom százalékában

A kérdőívek szerinti kérdésekre adott vállalati válaszok alapján rövid telefoninterjúk készültek. A kérdések spontán módon születtek, alapvetóen azokat a pontokat kerestük, ahol a válaszok a felajánlottaktól eltértek, ellentmondásra, félreértésekre utaltak, illetve gyéb kiegészítesekre szorultak.

VEZETÉSTUDOMÁNY
A legfontosabb célkitúzésünk az volt, hogy a válság hatását plasztikusan bemutató grafikonok készüljenek. A tervezés során egyértelmúen kiderült, hogy a vállalatok a válság hatásait elsôsorban a forgalo alakulásával, a forgalom visszaesésével mérik. Ehhez igazodva a tényszámoknál és a várakozásoknál is ezz mutatjuk be a válság hatásait. A tényszámokat a vállalatok természetesen ismerték. Az elórejelzéseknél más a helyzet. Nyilván a visszaesés tendenciája látható, de szükséges lenne a mértékek becslése is. Itt a rendkívill bizonytalan válaszok miatt olyan döntést kellett hozni, hogy a kérdések ne mértékekre, houn tendenciák tendenciák vonatkozzanak. Ezért az előrebecsléseket úgy kértük vállalkozóktól, hogy féléves pontossággal jelölje me azt az idópontot, amikor a válság eléri mélypontját, illetve azt, hogy mikor eni el ismet a 2008-ban jellemz forgalmat. Ebből következik, hogy az egyes válla kozók előrebecslési vonalai nem folytonosak (lásd 1. ábra).

A második részben a vállalati intézkedések jellegét kérdeztük meg. Itt a szakirodalomra támaszkodtunk, ezt igazolták a tesztkérdezések is.

A gazdasági-pénzügyi válságok egyik fontos jellemzóje, hogy kiszámíthatatlanok, a feltételek és a körülmények gyorsan változhatnak. 2010-ben ezét lefolytattunk egy második vizsgálatot, mintegy ezenlefolytat orizve, hogy a ván nyult-e. Kivanncsiak voltunk arra is, hogy az első femérés elónecsectei mennire volak helytalloak. Az eltelt egy év alatt a vállalkozások felmérhették helyzetüket és lehetôségeiket, válaszokat fogalmazhatta meg a válság kihivásaira, negkezdhettek az alkalmazkodást, illetve a jövôbeli fejlődés feltételeinek megteremtéseért is tehettek lépéseket. A 2010-es kérdó összeállitása során az alkalmazkodás és a jövőbeli fejlődés megismerésére helyeztük a hangsúlyt, változás mintázatokat kerestünk.

A megismételt vizsgálat új célja volt, hogy kisse részletesebben elemezzük, hogy milyen károkat, esetleg esélyeket hozott a válság. Ennek érdekében a kutatási módszert nemileg átalakítottuk, de vigyáztunk arra, hogy a két vizsgálat eredményei egymással összevethetôek legyenek, lehessen idősoros adatokat közölni.

A 2010-es kérdőív tartalma ennek megfelelóen változott, a 2009-es kérdő́ívnek a forgalom változásaira vonatkozó kérdéseit megismételtük, természetesen az évszámokat módosítva és az elôrejelzés időtartam hosszabbra szabtuk. Ismét rákérdeztünk a válságkezelO intézkedésekre. A kérdốiv harmadik részében a vállakozás átalakulására, átalakítására vonatkozó kérdéseket tettünk fel. A 2010-es kérdő́ív harmadik kérdéscsoporja az elsố vizsgálatban nem szereplố kérdések:
Milyen a vállalkozás helyzete most, 2010 elsố negyedévében (2008 végéhez képest), illetve azonos kérdések 2011 végére vonatkozóan:

Termék/szolgáltatási kör változása és összetétele Vevók, megrendelók változásai és összetétele

Elmaradt, csökkenó igény, illetve új vevók

Telephely mérete

Berendezések, termelöeszközök korszerüsége (minóségi összetétel változása)

Létszám változása, a munkatársak összetételének alakulása

ezetók létszáma, összetételének változása Nyereséghányad

Gép-és energiaköltségek aránya

Bérköltségek aránya

Anyagköltségek aránya

Alvállalkozói teljesitmények aránya

Marketingköltségek aránya

Egyéb igénybe vett szolgáltatási költségek aránya

Ezek a kérdések a vállalati gazdálkodás egészét igyekeznek átfogni, hogy rögzíthessük a vállalati erőorrások felhasználásának helyzetét 2010 első félévében. Kíváncsiak voltunk arra, hogy a gazdasági válsághoz történó alkalmazkodás hogyan befolyásolja a ö̈zeljövóben az erơf rrások felhasználását, kirajzolóiik-e a fejlod

A kérdốvek gyors feldolgozhatós

válaszáx́si lehetốś om vagy öt válós ran wagy out valaszlehetóséget kínáltunk fel (pl. váltoken, változatlan, nó, erôteljesen nố).

A megkérdezettek összetétele, kiválasztása több lépcső́ben történt. A vizsgálatokat alapvetően Győrre és környékének vállalkozóira terveztük. A kiválasztásnál korábbi kutatásainkra támaszkodhattunk (Rab - Szabó, 2001; Rab - Szabó, 2002). Ebből a körból került ki mintegy húsz, a második évben harminc eredményes megkérdezés, itt a visszautasít́s aránya 30\%-os volt. A tágabb kör mindkét évben negyven céget es vállaA tát jo kor int szintén Győrónl kiválasztva, a visszaA llként (j) yújiötttünk válaszokat, itt még nagyobb visszautasítás ányról számolhatunk be.

Az összetételt a következóképpen értékeljük: a vállalati nagyság magyarországi megoszlását jól leképezi (1. táblázat), az ágak szerinti megoszlás sem mutat jeentôsebb aránytalanságot (2. táblázat), a területi eloszlás pedig tudatosan választott. A tevékenységre és a fố termékre, szolgáltatásra vonatkozó kérdések együttesen azt bizonyítják, hogy - néhány kivételtól eltekintve - a

\section{VEZETÉSTUDOMÁNY}


vállalatok a reálgazdaságban tevékenykednek, maj nem kivétel nélkül magyar tulajdonúak, és az ún. valodi vállalkozások közé tartoznak, a saját tulajdonukba levő vállalkozásban valódi termelést és szolgáltatást, tényleges értékesítést végeznek. A 2010-es felmérés összetétele az első, 2009-es vizsgálathoz hasonlónak ítélhetố. A válaszadók területi elhelyezkedése szintén hasonló az első vizsgálathoz. Az első felmérésbe néhány szlovák, a másodikban a szlovákok mellett egy Romániában és egy Szerbiában múködő cég is belekerült a csoportba

\section{A gyorsfelmérések}

vállalati méret szerint megoszlása

(vállalatok száma)

\begin{tabular}{|l|c|c|}
\hline \multicolumn{1}{|c|}{ Vállalati méret } & $\mathbf{2 0 0 9}$ & $\mathbf{2 0 1 0}$ \\
\hline Mikrovállalkozások száma & 104 & 255 \\
\hline Kisvállalkozások száma & 24 & 55 \\
\hline Középvállalatok száma & 4 & 6 \\
\hline Nagyvállalat & 1 & 1 \\
\hline Összesen & 133 & 317 \\
\hline
\end{tabular}

feldolgozott minta száma 2010-ben azért nagyobb, mert a késóbbi részben olvasható elemzésekhez nagyobb adatmennyiséget láttunk szükségesnek.

A válaszolók összetételét összevont (és hiányos) nemzetgazdasági ág szerinti besorolásban mutatja a 2. táblázat.

A gyorsfelmérések ágazati megoszlás

(vállalatok száma)

táblázat

\begin{tabular}{|c|c|c|}
\hline Ágazat & 2009 & 2010 \\
\hline $\begin{array}{l}\text { Mezőgazdaság, vadgazdálkodás, } \\
\text { erdőgazdákodás, halászat }\end{array}$ & 8 & 10 \\
\hline Feldolgozóipar & 16 & 40 \\
\hline Építóipar & 14 & 36 \\
\hline $\begin{array}{l}\text { Kereskedelem, javítás, szálláshely- } \\
\text { szolgáltatás, vendéglátás }\end{array}$ & 56 & 150 \\
\hline Szálítás, raktározás, posta, távközlés & 12 & 38 \\
\hline $\begin{array}{l}\text { Pénzüigyitevékenysség, ingatlanügyletek, } \\
\text { gazdasági szolgáltatás }\end{array}$ & 14 & 28 \\
\hline $\begin{array}{l}\text { Oktatás, egészségügyi, szociális ellátás, } \\
\text { közösségi, személyi szolgáltatás }\end{array}$ & 13 & 15 \\
\hline Összesen & 133 & 317 \\
\hline
\end{tabular}

A két felmérés közül az általános nemzetgazdaság vállalati összetételhez a 2010-es áll közelebb.

\section{forgalom alakulása és elórejelzése}

A válság lefolyására vonatkozó tényadatokat és előrejelzéseket az adatbázisba rendezett adathalmaz alapján, ábrán mutatjuk be (1. ábra). Az ábrán a forgalom változásait index fejezi ki, ahol $2008=100 \%$.

Az ábra értelmezését segítik a következó adatok: a vállalatoknál a foglalkoztatottak száma átlagosan 91 , az alsó tizedben egyszemélyes vállalkozók vannak, itt az átlag 1 , ugyanez a felső tizedben 68 . Az egy évre vonatkozó forgalom átlaga 131 millió forint, az alsó tizednél 2,8, a felsônél pedig 1.020 millió forint (1. ábra).

Folyamatos vonal látható 2008 novemberétól 2009

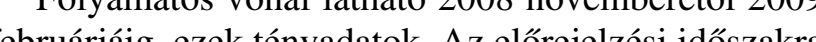
februajá, ezek tén vonatkozó várakozásokat szaggatott vonal jelöli.

A három vastag, kiemelt vonal közül a középsôt azonosíthatjuk a tênyadatok és várakozások kozzépértékével, ezt a vállalatok forgalmával súlyozott várható értékeként számítottuk. A másik két kiemelt vonal a felső és az alsó decilisbe esố vállalat adatainak szintén a forgalommal súlyozott várható értéke (2. ábra).

A 2. ábrán a nemzetgazdasági ágak szerinti rendezésben adjuk meg a válság lefolyására vonatkozó elôrejelzéseket. A vonal az elózóekhez hasonlóan szintén a forgalommal súlyozott várható érték, a részleteket, a vállalatok egyéni vonalait itt mellóztük.

Ugyanilyen módon mutatjuk be a vállalati nagyság szerinti megoszlást a 3. ábrán, az egy nagyvállalat természetesen hiányzik (3. ábra).

A két vizsgálat eredményeinek összevetésére alkalmas a 4. ábra. Itt a 2009-es és a 2010-es adatok együtt láthatók. Az ábra segítségével összevethetô a vállalkozások 2009-ben adott forgalmi elốrejelzése a 2010 tavaszán megadott tényadatokkal. Az ábrában bejelöltük a kérdezések idópontját, fekete folytonos és szaggatott vonallal jelöltük a 2009-es tényadatokat és elórejelzéseket, szürke folytonos és szaggatott vonallal a 2010-ben közölt tényadatokat és a forgalom becslését (4. ábra).

Megállapíthatjuk, hogy a tavalyi előrejelzések nem bizonyultak túlzottan pesszimistának, bár a forgalom csökkenése kissé enyhébb volt az elôre jelzettnél, a válság lefolyásának karakterisztikája lényegében a vállalkozói várakozásoknak megfelelóen alakult. A középső vonal a 2010-ben közölt forgalmi tényadatok kedvezóbb alakulását mutatja, mint az erre az időszakra 2009-ben adott becslés. A 2010-es elórejelzés viszont óvatosabb, mint a 2009-es. A felsố decilis tényadatai 2009-ben rosszabbak, mint a 2009-es becslések, az optimistábbak rosszabb helyzettel szembesülhettek. Az alsó decilis tényadatai és elórejelzései változatosabb képet mutatnak.
A forgalom alakulása a 2009-es felmérés szerint

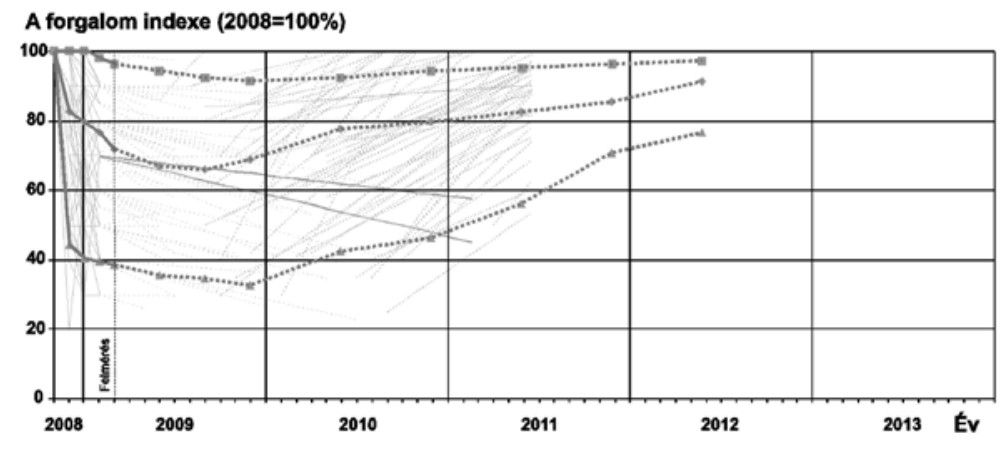

A forgalom alakulására vonatkozó előrebecslések tevékenység szerint

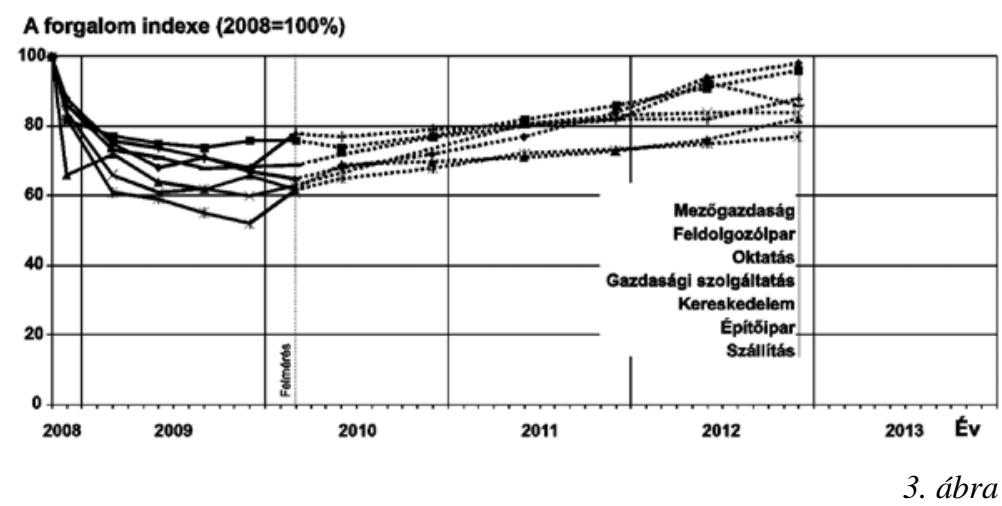

A forgalom alakulására vonatkozó elốrebecslések vállalati nagyság szerint

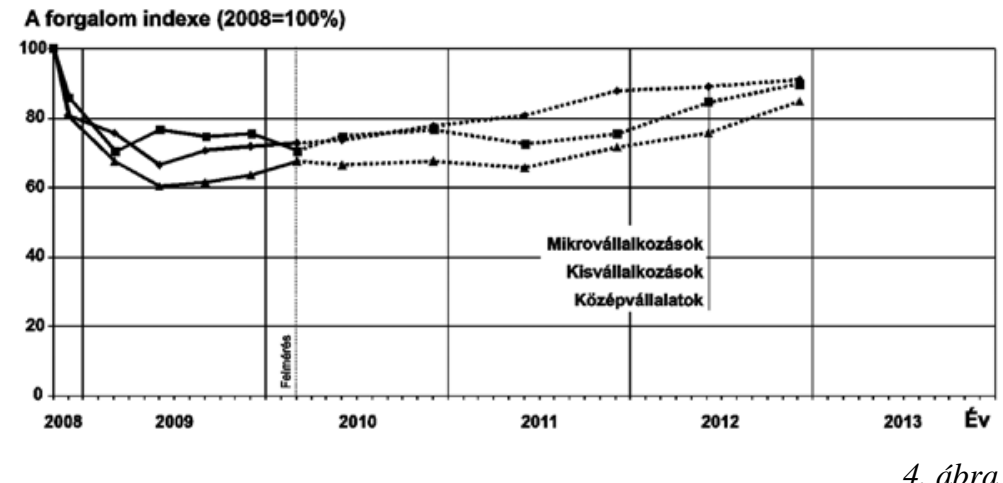

A két felmérés forgalmi indexeinek különbsége

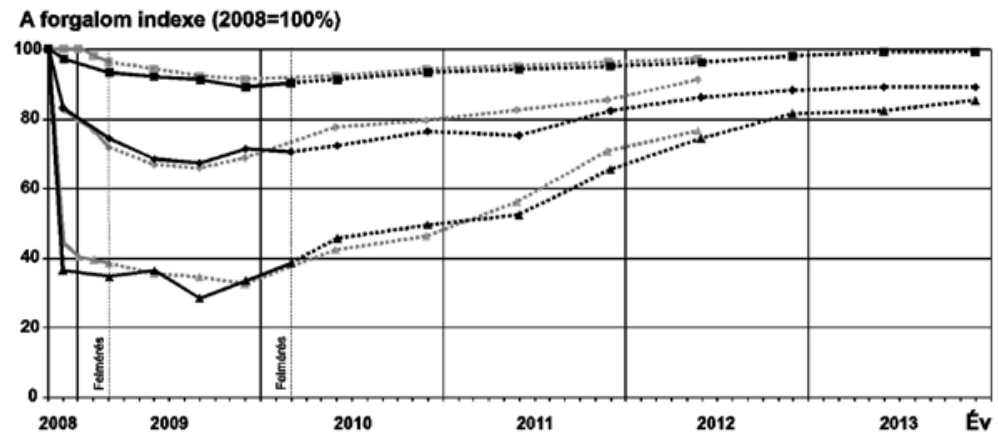

$2013 \quad \mathrm{E}^{2}$
Az ábrák egyértelmú tendenciát mutatnak: 2009-ben erós forgalom-visszaesés, 2010-ben pedig stagnálás és kismértékú javulás, ritkábban további romlás figyelhetô meg. A jövốre vonatkozó várakozások hosszan elnyúló válságot vetítenek elő.

\section{A válság kezeléséról 2009-ben}

A válság elójelei 2008. szeptember-októberben jelentkeztek. A vállalkozók beszámoltak arról, hogy a sajtóból és egyéb hírforrásokból tájékozódva hallották elôször a rossz híreket. Ezután általában megkülönböztettek egy második fázist, amikor megérkeztek az elsố piaci jelzések, a rendelések csökkentek, akadoztak, a kapacitások kihasználása egyre nehezebbé a kapacitások kihasznalása egyre nehezebbé
vált. Késóbb a banki múveletek nehezedtek meg, a befektetések értéke csökkent, egyes befektetési pozíciókból már nehezen, késleltetve vagy veszteségekkel lehetett szabadulni. Decemberben már egyértelmúen késtek a vevơi kifizetések, az új évben már egyértelmúvé vált, hogy gazdasági válság van, és ez a vállalatot közvetlenül érinti.

Az elôző ábrákon világosan látszik, hogy 2009. decembertől 2010. február végéig szinte mindenhol visszaesés következett be, és a visszaesés nemegyszer rendkívül nagymértékú. A cégek többsége azonnal rendkívüli intézkedéseket hozott, ezek az esetek túlnyomó többségében arányosak a visszaesés mértékével. Tendenciaszerúen állítható, hogy a kisebb visszaesést elszenvedett vállalatoknál a dologi költségekkel való takarékoskodással, a beruházások, fejlesztések lassításával, ha ez lehetséges volt, halasztásával kísérleteztek. Általános az óvatos takarékoskodás a bérköltségekkel: fizetéscsökkentésról, átmeneti munkaidő-csökkentésekról, részfoglalkoztatásra való áttérésról számoltak be ott, hoz a visszaesés nagyobb, esetleg kiug ott, a nagymétćkú volt. Kulonôsen a nagyobb mérétu vallalatok voltak kénytelenek jelentős létszámcsookkentést végrehajtani, gyakran hangoztatták ezeknél a cégeknél azt, hogy a túlélés egyetlen esélye a telephelyek egy részének átmeneti, de teljes leállítása, és a létszámcsökkentés, az adminisztráció egyszerúsítése. Sokan próbálkoztak a hitelek átütemezésével, a befektetések portfóliójának átalakításával, a banki költségek csökkenté- 
sével. (A választ adó vállalkozók eladósodottságának mértéke nem volt jelentôs, a kisvállalkozók alacsony vállalati adósságszolgálatról számolnak be, és magánszemélyként is óvatos hitelfelvevôknek tüntek.) Sok cég számolt be arról, hogy kénytelen volt halasztan szállítói kifizetését.

A forint árfolyamának alakulása a többséget nehéz helyzetbe hozta. Az importárak növekedése áremelésre kényszerített sok vállalkozót, de a piac csak részbe fogadta el ezeket a törekvéseket. Gyakori volt a 2008 kora ôszén megkötött szerzódések újratárgyalása. Né kora ószén megkón a hány terưleten (mintánkban a fuvarozó szolgáltatókn jellemzó) a kereslet szúkülése kíméletlen árverseny indított, ennek hatásai a 2009-es felméréskor még kiszámíthatatlanok voltak. A vállalatok kutatták az al csonyabb árú beszerzési forrásokat, belföldi helyett
külföldieket, vagy fordítva. Jellemzô a marketingkölt-

külföldieket, vagy fordítva. Jellemzó a má
ségek csökkentése, néha teljes kiiktatása.

Volt egy réteg, amelyet akkor még nem érintett olya súlyosan a válság: a külföldiek beszállítói jellemzóen euróban számolnak el, az árfolyam emelkedése részben ellensúlyozta a teljesítmény csökkenését. (Részben ez adott magyarázatot arra, hogy a feldolgozóipari vállalatok várakozásai az átlagosnál derúlátóbbak.

Sokszor elhangzott ekkor, hogy a válsággal kapcsolatos intézkedések mértéke túlzott, a vállalkozók túlzott reakciókkal, a várhatónál rosszabb helyzethez illóen válaszolnak a visszaesésre. Néhány megkérdezettnél az adatokból akkor is így látszott. Kérdésre elmondták, hogy addig a jó üzletmenet elfedte a kapacitásfelesleget, nem volt idó a folyamatokban levő tartalékok feltárására, de a kényszer sok ilyen jelenséget felszínr hozott, és ebben a helyzetben a ki nem használt eróforrások megszüntetése mellett döntöttek.

A következő kérdések már a jövőre vonatkoztak, különféle idôszakokra értelmezve, de azonos tartalommal. A 2009 első félévére tervezett intézkedések elég határozottak voltak, még jól körvonalazhatók a második félévre előirányzottak, és rendkívül bizonytalanok a késóbbiek. Több vállalkozótól hallottuk azt a fordulatot, hogy most múr éćgé benne vagyunk, kezdin latot, hogy most mu eleggé be ne vank, kezdünk hozzászokni, vannak ötleteink, hogyan kell reagálni. A közeljövôn a takacekosság folytatása, sőt fokozás és az eróforrások fokozatos leépítése volt nagyon jelemzó, tervek készultek erre. Tudatosan csökkentetté a készleteket, áttertek a csak rendelésre történó gyártásra, illetve beszerzésre, a foglaló jellegú részfizetésekr a megrendeléskor. Sokan bíztak a banki kapcsolatok normalizálásában, a fizetési készség javulásában. További tőkeemelésre, pótlólagos tôke bevonására általában nem készültek, a tartalékokat - ha voltak - későbbre tartogatták. Sokan bíztak az állami megrendelések növekedésében. A 2009 első félévében várható intézkedések tehát az eddigiekhez hasonlóaknak, de sokka tervszerúbben végrehajtottnak ígérkeztek.

Volt a vizsgált vállalatoknak egy figyelemre méltó csoportja. Ốk nem csak takarékoskodtak, náluk a válság a cselekvés, a fejlesztés ideje. Nyilatkozatuk szerint a válságra adandó válasz a piackutatás intenzívebbé tétele, illetve a vevôi igényeknek az eddiginél is alaposabb vizsgálata. Tehát az ô receptjük az általános szemlélettel szemben: a gyengülố kereslet kielégitése mellett - a nyereségszint átmeneti csökkenését

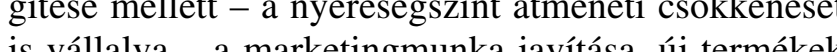
bevezerise a mo le liink es esoozzzel. ("Talpalunk, mindenkit kérdezünk, hogy mit venne, egyéni igényeket próbálunk kielégíteni, majd az így kialakított új termék- vagy szolgáltatásfajtát másnak is eladjuk. Megkeressük régi vevőinket, újakat keresünk, mindenkit ajánlatokkal bombázunk, már kezdeti sikereink is vannak.”) Ötletgyújtésre és termékinnovációra, piacmegdolgozási technikákra, fejlesztésekre projekteket indítottak. E csoport néhány tagja úgy nyilatkozott, hogy most nem a bezárkózás, hanem az együttmúködés lehet sikeres, vagyis társakat keresnek, hálózatokhoz kívántak csatlakozni, együttmúködéseket terveztek. A válság megváltoztatja a vezetés stílusát is.

2009 második félévére, ez az 1. ábrán is látható, már sokan reméltek enyhülést, javuló tendenciára számítottak, de sokan gondolták éppen az ellenkezőjét. A fellendülésre számítók az elmaradt fejlesztések folytatására, és pótlólagos pénzügyi eszközök keresésére koncentráltak. Számítottak a javuló gazdaság adta konjunktúrára, fóként az elốbb bemutatott dinamikus vállalkozói csoport. Az egy-két személyes vállalkozások jövedelmük csökkenését várták, alapvetố stratégiai iránynak túnt az alacsonyabb árakkal való versenyben maradás, az így elért kisebb nyereség mellett. Kitartásra, túlélésre rendezkedtek be, alkalmazottként való elhelyezkedésïkre általában nem gondoltak, nem is láttak erre lehetóséget.

2010-re a többség már növekedést várt. Készültek az újból meginduló versenyre, és ezt úgy képzelték el, hogy az körülbelül a régi szabályok és körülmények között fog folyni. A lehetséges intézkedéseknél erre az idôszakra lényegesen kevesebben említették a takaréosságot, a létszámcsökkentést, egyre gyakoribb volt az a válasz, hogy nem lesz szükség rendkívüli intézkedésekre. Mindenki arra számított, hogy a bankok és hitelintézetek helyzete stabilizálódik, és a finanszírozás rendszere akkor már olajozottan múködik, a fizetési fegyelem és hajlandóság is javul. Ezek már egy javuló gazdasági helyzetre utaló várakozások voltak.
A megismételt vizsgálat 2010 márciusában az elóbbi tendenciákat erősítette meg. A már bemutatott ábrák szerint a 2009. év tényadatai nagyjából a korábbi elorebecslésnek megfelelôen alakultak, az eltérés jelentéktelen. A távolabbi jövớre vonatkozó előrebecslések ugyanolyan mértékben bizonytalanok. Talán azt lehet megállapítani, hogy a válság oldódását a vállalatok kissé későbbi időpontra várják.

\section{A változtatás mintázatai a kis- és középvállalati} szektorban

A 2010-es felmérés fố célkitűzése az egyes vállala tok változási tendenciáinak vizsgálata. A fó kérdés az, hogy a kérdésekre adott válaszok, a számszerú értékek és a válaszoló prognózisa szerint az egyes vállalatok mennyiben felelnek meg vagy térnek el az általáno tendenciától. Az elemzés alapján válaszolhatunk ar a kérdésre is, hogy mi változott a vállalatok múködés módjában, gazdálkodásában a válság hatására, vagy másképpen: miben különböznek várhatóan a válsâg utáni cégek korábbi önmaguktól.

A 2010-es kérdőíveket újfajta módon elemeztuik. A vállalat tevékenységét három szempont szerint vizsgáltuk meg. A szakirodalomban széles körben ismert a vállalati tevékenység gazdálkodási és vállaben ismert ácí vâllalati tevékenység gazdallkodási és vallallkozoi rèsz harmadikat is, azt, hogy milyen, a jövő́beli fejlôdés harmadikat is, azt, hogy milyen, a jövóbeli fejlődést megalapozó intézkedésekre volt képes egy-egy cég, ezt fejlódési potenciálnak nevezzük. A három tevékenység egymástól nem választható el egyértelmúen, ezért az
egyes tevékenységeknél figyelembe vett kérdốivi elemek átfedik egymás

Mindegyik szempontnál három fokozatot különböztetünk meg. Közepesnek nevezzük azt, ha egy vállala az általános, átlagosnak ítélhetố eredményeket érte et, a szokásosnak tekinthetố válságkezelő intézkedéseket hozta, helyzete, jövốbeli lehetôségei is átlagosak. A közepestól eltérés nyilván kétféle lehet, vagy a ros vagy a jo i

A vállalkozási tevékenység megítélésében figyelembe vettük a forgalom alakulását, a nyereségarány változását, a termékkör változásait, a marketingre fordított erôforrásokat és a vevókör viselkedését (számuk alakulása, cserélő́désük). Közepesnek tekintettük azt, ha a vállalat 2009-ben 25-35\%-os forgalomcsökkenés szenvedett el, majd 2010-ben a coögkenés lényegese enyhült, a forgalom stagnált vagy kismértékben eme kedett, és ugyanakkor a termékkör lényegében változatlan maradt, a vállalat kínálata nem változott, és nem változott a marketingmunka sem, a vâllalat várakozás szintén az átlagnak megfelelőek. Gyengének minősítettük a vállalatot, ha forgalma 2009-ben az átlagnál nagyobb mértékben csökkent, vagy a válság kezdete óta allandóan csökken, a nyereség visszaesett, a termékválaszték zsugorodik, vevői elhagyják, a marketingeszközök bevetésére esélyt sem lát. A gyenge vállalat a túlélésért küzd, a jövóben legfeljebb a fennmaradás esélyét látja. Erősnek minôsül az a vállalat, amelyik nem szenvedett el lényeges forgalom- és nyereségcsökkenést, esetleg a forgalom növekedéséról számolt be, orgalma rövid esés után újra emelkedett, termékköre legalább részben megújult vevő́i nem hagyták el vagy pótolni tudta óket, a marketingmuka intenzitáśt a válságévekben fokozni tudta, és mindemellett várakozásai a jövốre nézve optimisták.

A gazdálkodásnál üzemgazdasági jellegú elemeke tékeltünk. Közepesnek itt azt tekintettük, ha a vállaat forgalmi és nyereségadatai átlagosak voltak, a költségszerkezet nem változott lényegesen, nem csökken drasztikusan a létszám, az egyes költségtényezók nagyobb változásaira a vállalat nem is számít. A vállalat a válságra az általános válaszokat adta: kismértékú személyzetcsökkentés, munkaidô-csökkentés, szokványos takarékossági intézkedések. A gyenge vállalatnál a foralmi és nyereségadatok gyengék, a vállalat költség-

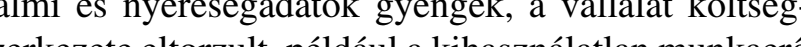
söltsége megnőtt a többi költség rováśa, valaero válla ment a a vallalat nem számít egy egészséges költségszerke-

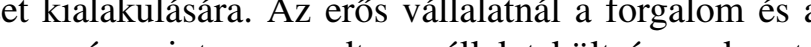
nyereség szinten maradt, a vállalat költsegszerkezete viszonylag stabil, a kintévôségek minimálisak, a válalat fizetóképes, hitelképes, a beruházások nem álltak le, a marketingköltségek nôttek, a vállalat nem számít lényeges torzulásokra.

A fejlốdési potenciál szempontjából a vállalat akkor közepes, ha a személyi, munkatársi és vezetối kör nem változott, a termékek, a választék hozzávetốleg változatlan maradt, a cég tốkéje nagyjából változatlan, a telephelyek nem változtak, beruházásokra nem gondolnak, a marketingaktivitás nem élénkïil. A gyenge vállalat tókéjét éli fel, ennek pótlására nem képes, tevalla 作, vezetó megmaradnak, munkatársainak nagy részét elveszti. me corési pont nem látszik. Ebbôl a szenponbol a vállalat erôsnek számít, ha a személyzet minőségi javuláson ment át, ugyanez vonatkozik a vezetốkre is, a vállalat pótló tókéhez jutott, új termékekkel jelentkezett, új vevő́kkel rendelkezik, marketingaktivitása nagyobb, növekedési terveket készít.

Az összes vizsgált vállalat besorolása a három szempont szerint a 3, táblázat szerinti eredményre vezetett. 
A vállalati tevékenység fokozatainak megoszlása (vállalatok száma)

\begin{tabular}{|l|c|c|c|}
\hline \multicolumn{1}{|c|}{ Szempont } & Közepes & Erốs & Gyenge \\
\hline Vállalkozás & 174 & 77 & 66 \\
\hline Gazdálkodás & 230 & 40 & 47 \\
\hline Fejlódési potenciál & 241 & 29 & 47 \\
\hline
\end{tabular}

A következő táblázatsorozat az ágazati különbségek tanulmányozását is lehetôvé teszi (lásd 4. táblázat).

A vállalati tevékenység

4. táblázat

ása ágak szerint (vállalatok száma)

\begin{tabular}{|c|c|c|c|c|c|c|c|c|}
\hline & & & & Ag/MHLtazal & & Fyertes & vesztes & vállalą \\
\hline Szempontok & Közepes & Erốs & Gyenge & Mezőgazdaság & 10 & 0 & 0 & 10 \\
\hline \multicolumn{4}{|c|}{ Mezógazdaság } & Feldolgozóipar & 18 & 4 & 12 & 34 \\
\hline Vállalkozás & 8 & 1 & 1 & Épitő́ipar & 18 & 2 & 7 & 27 \\
\hline Gazdálkodás & 9 & 0 & 0 & Kereskedelem & 90 & 16 & 20 & 126 \\
\hline Fejlódési potenciál & 10 & 0 & 0 & Szállitás & 21 & 5 & 2 & 28 \\
\hline \multicolumn{4}{|c|}{ Feldolgozóipar } & & & & & \\
\hline Vállalkozás & 21 & 5 & 14 & kenység & 16 & 4 & 0 & 20 \\
\hline Gazdálkodás & 20 & 5 & 15 & \multirow{3}{*}{$\begin{array}{l}\text { Oktatás, } \\
\text { egészségügyi } \\
\text { szolgáltatás }\end{array}$} & \multirow{3}{*}{6} & \multirow{3}{*}{1} & \multirow{3}{*}{1} & \multirow{3}{*}{8} \\
\hline Fejlódési potenciál & 20 & 5 & 15 & & & & & \\
\hline \multicolumn{4}{|c|}{ Épitóipar } & & & & & \\
\hline & 20 & 6 & 10 & Összesen & 179 & 32 & 42 & 253 \\
\hline
\end{tabular}

Elemzési módszerünkkel összesen 253 vállalat fejlódési tendenciáit tudtuk egyértelmúen valamelyik mintázatba besorolni. A teljes számból hiányzó vállalatok az ismertetett értékelési szabályok egyikének sem feleltek meg (64 vállalat, 20,2\%).

Az alapmintázatot követô vállalatok aránya természetesen mindenhol magas, de mégis vannak különbségek. A mezőgazdaságnál csak ilyet találtunk, igaz, felmérésünket még a katasztrofális idójárási idốszak elốt készítettïk. Ebon az eredményben az agrárzak elôt keszitettuk. Ebben az erednényben az agrárágazat sajátosságai is szerepet kapnak. termelési ciklusok miatti hosszabb reakcióidó a gazdasági valtozásokra, tartalékolás és ônfogyasztás viszonylag magas szintje. A szélsốséges mintázatok nagyobb arányát produkálták a kereskedelem és a mellé sorolt ágazatok vállalatai. A szállításnál, a pénzügyi tevékenységnél és az egyéb szolgáltatásnál a megoszlás viszonylag kiegyensúlyozott.

Az eredmények értékelésénél ne feledkezzünk meg arról, hogy az alapmintázatot követő vállalatok is súlyos veszteségeket szenvedtek el. A nyertesek csak eh-

VEZETÉSTUDOMÁNY hez képest voltak képesek a fejlődésre, a válság általában náluk is károkat okozott. Összességében a vesztes vállalatok száma meghaladja a nyertesekét. A vesztes mintázatot követố vállalatok a túlélésért küzdenek, átalában reménytelen helyzetben vannak (6. táblázat).

Termeló és

6. táblázat szolgáltató-ágą̧ változási mintázatai (\%-ban)

\begin{tabular}{|l|c|c|c|c|}
\hline Ág/Mintázat & Alap & Nyertes & Vesztes & Összesen \\
\hline Termeló-ágazatok & 65 & 8 & 27 & 100 \\
\hline $\begin{array}{l}\text { Szolgáltató } \\
\text { ágazatok }\end{array}$ & 73 & 14 & 13 & 100 \\
\hline
\end{tabular}

Megjegyzések: Szolgáltatóágazatok: kereskedelem, szállítás, pénzügyi tevéke ség, oktatás és egészségügyi szolgáltatás

A vállalati viselkedés, alkalmazkodás mintázataina érdekes képe rajzolódik ki, ha termelő- és szolgáltató ágazatokba vonjuk össze a korábbi ágazati felosztást. A termelố ágazatokban magasabb a vesztes típusú vállalatok aránya mint a szolgáltató csoportban. A nyertes szolgáltató vállalatok aránya értékelhető́n magaertes szolgalo villo mint a tero veckón az

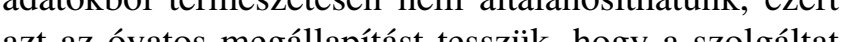
azt az óvatos megállapitast tesszlk, hogy a szolgaltat vállalatok közül viszonylag több tudott sikeres választ adni a válság által támasztott kihívásoknak, mint a termeló szektorban.

\section{Az interjúk tapasztalatai 2010-ben}

A 2009. évi felméréshez hasonlóan most is rövid interjúk készuiltek személyesen vagy telefonon, és az anyagot a kérdőívek mellékleteként kezeltük. A korábbi tapasztalatok alapján most megadtunk néhány általános, javasolt interjúkérdést. A válaszok többsége ezekról szólt, de volt néhány érdekes egyéb téma is.

A válság hatására megváltozott-e a vállalkozók együttmúködése? Erre a kérdésre nagyon kevesen adták azt a választ, hogy a vállalakozók együttmúködése a válság hatására erớsödött volna. A leggyakoribb válasz az volt, hogy a korábbi együttmúködési készség is gyengült, a gyengüló forgalom, a megrendeléseké folyó harc miatt. A közös erő́feszítésekkel küzdeni válság ellen jellegú válasz csak elenyészó arányban, kivételként volt megfigyelhetố.

Milyennek látja a fennmaradás és a fejlődés lehetôségeit? A válaszolók általában hangsúlyozták optimis vagy pesszimista beállítódásukat, és ennek megfelelô- en adtak választ. Az optimizmust az táplálja, hogy már gyengült a válság szorítása, az eredmények, ha nem is javulnak, de nem romlanak látványosan. Érdekes módon a pesszimista és az optimista szemlélet nem mindig uugg össze a vállalat által követett mintázattal.

A válság kezdete óta milyen kapcsolatokat épített ki a cég? A kérdést a leggyakrabban úgy értették, hogy milyen üzleti partnereket szereztek a vállalatok a válság alatt. A leggyakoribb, az együttmúködésre adott válasszal azonos jelentésú, beszúkülésre, ajánlatok elutasítására panaszkodnak.

Melyek a válságban szerzett legfontosabb tapasztalatok? A válság leginkább egyértelmú jele a vállalatok számára a forgalom visszaesése, amely kikövetelte a sokszor drasztikus, a vállalatok által nem megszokott válaszokat és intézkedéseket. A kérdésre adott válaszok nagyon eltérnek egymástól, egyértelmú tendenciât nehéz itt közölni.

Sokan látják a vállalat rossz helyzetének okát a tókehianyban, a túlzott kapacitásokban, de ennek az ellenkezôje is elôfordul. Van, aki a vállalatot túlméretezettnek gondolja, és a válságot a kisebb méret kialakitási esélyének látja, de van, aki éppen ellenkezóleg, azt gondolja, hogy saját vállalata jobban tứrte volna a válságot, ha nagyobb, erôsebb, a piacon nagyobb tekincélyúu lett volna.

A vállalatok egy része a termékkör korlátozottságát, másik részük pedig a túlzottan szétágazó választékot artja hibának. Ebben a kérdésben a többség a több lábon állás helyessége mellett voksolt.

A standard kérdések mellett számos érdekes egyéb megállapítást is összegyúijtöttünk, ezek összefoglalására most nem vállalkozunk. Egy témát viszont meg kell említeni, ez a válság lélektani hatása. Társadalomtudományi kutatásokat igényelne a részletes elemzés, ezt mi itt meg sem kíséreljük, csak jelezzük, hogy ez fontos kérdés. Sok vezetó és tulajdonos számolt be a cég és saját, valamint munkatársai sorsáért való aggódásról, amely növelte a stresszt, és a lehetségesnél is gyengébb teljesítményt okozott Többen kiemelték, hogy a válság

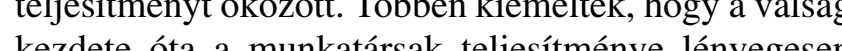

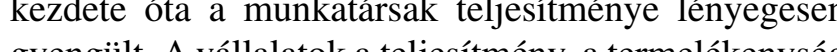
vagy a héck vor a hatikus som áś szor drasztikus romlására hívták fel a figyelmet. A magyarázatok eltéróek, de a munkahely elvesztésétól való félelem, a kevesebb munkával kitölteni kívánt munkadő, a munkalassítás általában szerepel köztük.

Rooseveltnek tulajdonítják a következő mondást: Minden válság esély: a régi struktúrákat szétverni és jobbat csinálni. Vizsgálatunkból arra következtethetünk, hogy ebben az esetben ez csak keveseknek fog sikerülni.

\section{VEZETÉSTUDOMÁNY}




\section{Összegzés}

Egyre biztosabban állítható, hogy a 2008 végén kezdôdô pénzügyi válság és a kialakuló általános gazdasági válság hatásai hosszabb idôn át éreztetik hatásukat. Nemzetgazdasági szinten jól láthatóak a tendenciák, amiket a szokásos mutatókkal (pl. GDP alakulása) érzékeltethetünk. Az ágazati, a területi és a vállalat nagyság szerinti kutatások árnyalhatják, pontosíthatják az aggregált ismereteket. Kutatásunk alapvetően Gyôr és kornyékén múködó kis- és középvállalato válsággal kapcsolatos reakcióival foglalkozik. A 2009 és 2010 tavaszán elvégzett adatgyuujutések elókészítese során a kutatás-módszertani alapelvek megtartá mellett az egyszerúségre és a gyors feldolgozhatóság ra törekedtün. A kêt felmérés kôzôtti idóben törté gazdasági változások miatt természetesen a 2010-e kérdőív nem egyszerúen a 2009-es ismétlése, pontosítottuk a válságkezeléssel kapcsolatos kérdéscsoporto A zárt kérdések mellett mindkét felmérés alkalmával lehetőséget adtunk a vállalati sajátosságok rögzítésére, nyitott kérdésekkel.

Felméréseink egyik eredménye az elhúzódó válság hipotézisének a megerósítése. A forgalom visszaesêsével kapcsolatos 2009-es várakoź́sokat a tónyadatok sével kámaszották. A jövóbeli kilátásokra vonatkớ op-

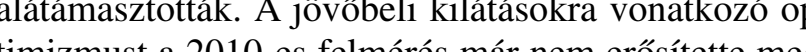
timizmust a 2010 jes felméc a válságból való kilábalás idő́pontját késóbbre tették
vállalatok.

2009-ben a válságkezelés a hagyományos eszközök alkalmazásával vette kezdetét: a kötelezettsége teljesítésének átütemezése a likviditás fenntartása érdekében, a költségek csökkentése. A válság mélyülé sével a piaci kapcsolatok és az eróforrások hosszabb távra ható átrendezése is megkezdődött: értékesítés stratégia hozzáigazítása a változó kereslethez és igényekhez, kapacitások és készletek leépítése. A kérdôivek értékelése során azonosítottuk a vállalatoknak egy figyelemre méltó csoportját, rájuk a takarékosség melletti fejlesztés a jellemzó. Nemcsak piackosság

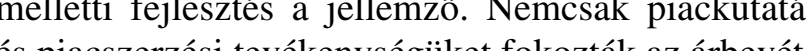
es piacszerzesi tevé jenységiket fokozták az árbevéte szinten tartasa érdécben, han uj tentúkek, szolgá tatások fejlesztésére fordították szúküló forrásaik egy jelentốs hányadát.

A 2010-es felmérés alapján két lépésben határoztuk meg a vállalati változások mintázatait, alap-, nyertes és vesztes mintázatot különböztettünk meg. Elsô lépésben a vállalatok tevékenyégét gazdálkodási, vállalkozási és fejlődési potenciál szempontok szerint értékeltük. Fejlődési potenciál alatt azokat az intézkedéseket értjük, amelyeket a vállalatok a jövôbeli fejlődés megalapozása érdekében tettek meg (pl. innovációs kiadások növelése).
Mindegyik szempontnál három fokozatot állapítottunk meg. Közepessel jelöltük a szokásos, átlagos válságkezelési és fejlesztési intézkedéseket megvalósító vállalatokat. A közepestól való pozitív eltérést erôs, míg a negatív eltérést gyenge fokozatnak tekintettük. A második lépés a szempontok együttes értékelése, a vállalatok válságbeli magatartásának minôsítése, a vállalatok változási mintázatok szerinti besorolása volt. Alapmintázathoz soroltuk azokat a vállalatokat, amelyek két vagy három tevékenységi szempont alapján közepes, esetleg egy szempontból gyenge, vagy erós értékelést kaptak.

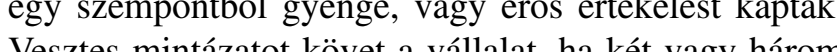

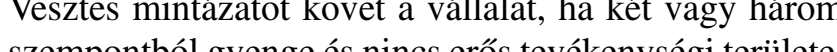
Nyen on rom szempont erôs, vagy két erós és egy közepes értékeésú szempont jellemezte a vállalatot.

Fontos megállapítás, hogy a vállalatok többsége csak a szokásos módszerekkel kezelte a válságot, nem tett semmit a jövốbeli fejlódés feltételeinek megteremtéséért, a vállalatok $71 \%$-a sorolható az alapmintázatba és $16 \%$ a vesztes mintázatú. Kevesen vannak a nyertes mintázatba tartozó vállalatok, csak $13 \%$ az arányuk. Kutatásunk megerôsíti az ismert ágazati sajátosságokat: a feldolgozó- és építóipart súlyosabban érintette válság, a vizsgált minta átlagánál jóval magasabb a vesztes mintázatúak ánya (35 ́́s 26\%). A szolǵlta ó ágzato válla jálató lagná lagnál magasabb az alap- és a nyertes mintázatba sorolt
cégek aránya.

\section{Felhasznált irodalom}

Barberis, N. - Thaler, R. (2003): A survey of behavioral finance. in: Handbook of Economics and Finance, M. Harris and R. Stulz (eds.), Elsevier Science, p. 1052-1114.

Fischer, G. - Lee, J. - Johns, L. (2004): An exploratory study of firm turnaround in Australiaand Singapore following
the Asia Crisis. Asia Pacific Journal of Management, $21,149-170$

Fodor P. - Poór J. (2009): Begyưurúzó gazdasági és pénzügyi események. Várható változások a vállalati menedzsment, a bérezés és a HR területén. Kutatási zárójelentés (http:// www.bkik.hu/download/Globalis_krizis_hatasai_ jelentes_2009_03_03.pdf).

Hoskisson, R. - Eden, L. - Lau, C. - Wright, M. (2000): Strategy in emerging economies. Academy of Management Journal, 43, p. 249-267

Király J. - Nagy M. - Szabó E. V. (2008): Egy különleges esemenysorozat elemzése - a másodrendú jelzáloghitelpiaci válság és (hazai) következményei, Közgazdasági Szemle, LV. évf., 2008. július-augusztus, 573-621. old. $K K V$ helyzete (2007) $=$ A kis és középvállalkozások helyzete 2007, Nemzeti Gazdasági és Fejlesztési Minisztérium

VEZETÉSTUDOMÁNY
Kopint-Tárki $(2010)=$ A világgazdaság és a magyar gazdaság helyzete és 2010. évi kilátásai. KopintTärki tanulmany, Budapest, 2010. február 28.

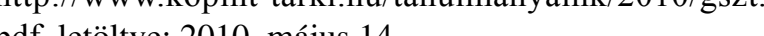
df, letôltve: 2010. majus 14

Krugman, P. (Ed.) (2000): Currency crisis. University of Chicago Press, Chicago

Losoncz M. (2008): Az amerikai hitelválság és világgazdasagi következményei. Pénzügyi Szemle, LIII. évf., 2008. 2. szám 248-264. o.

Losoncz M. (2009): Adósságválság felé? Válságnapló 2009 február. Elet és Irodalom, 2009. február 27. 3. o

Losoncz M. (2009a): Válság, válságkezelés és reformok. Élet és Irodalom, 2009. április 3.3. o.

Magyar gazdaság 2008/IV Nemzeti Fejlesztési és Gazdasági Minisztérium Stratégiai Főosztály, 2009. márciu

Magyar gazdaság 2009/4. Nemzeti Fejlesztési és Gazdasági Minisztérium, Gazdaságpolitikai és Elemzési Fôosztály, 2010. március

Petrik R. (2009): Kiút a válságból. Export recesszió idején, Business Provider Group (http://www.bpgroup.hw/ article_156-hu.html)

Rab K. - Szabo J. (2001): Sikerkönyv. PMS, Budapest

Rab K. - Szabo J. (2002): Kihívás - siker. Beszámoló egy

Sawyerr, O. (1993): Environmental uncertainty and environmental scanning activities of Nigerian manufacturing executives: A comparative analysis. Strategic Management Journal, 14, 287-299. p

Small businesses' confiden SME surey pdf/090311_Barometer_2009-H1_FINAL.pdf.

zzabó J. - Császár G. (2004): Húsz év vállalkozáskutatásai Magyarországon. Vezetéstudomány, 35. év. 4. sz.

tés (2008). A magyar valla latok fejlodési fázisai. Vezetéstudomany, $39.6 \mathrm{ve}$. $10 . \mathrm{sz}$ sok. Vállalkozás és Innováció, 3. évf. 1-13. old

evolu - Romalli, E. (1985). Organizational evolution. A metamorphosis model of convergence and reorientation. in. Cummings, L.L. - Staw, B.M. (Eds.). Research in Organizational Behavior, Greenwich, CT. JAI Press, p. 171-222. right M. Filatotchev, Strategy reserch i. - Hoskisson, R. - Peng, M. (2005): Strategy research in emerging economies: Challenging the conventional wisdom. Journal of Management Studies, 42 , p. 1-33.

Cikk beérkezett: 2010.7 hó

Lektori vélemény alapján véglegesítve: 2010. 8. hó

\section{KÖZGAZDÁSZ VÁNDORGYÜLÉS}

VERSENYKÉPESSÉG ÉS ADÓSSÁGCSÖKKENTÉS - ez lesz a címe

a 49. Közgazdász vándorgyúlésnek, amelynek ebben az évben Pécs városa ad otthont 2011. szeptember 29. és október 1. között.

Az államadósság csökkentése és a nagy állami rendszerek (a nyugdíjrendszer, a szociális támogatások, az egészségügy, a köz- és felsőoktatás) $k \ddot{u}$ szöbön álló átalakitása, a foglalkoztatás bövitése és a nagy közmunkaprogramok tervezett elinditása, a versenyképesség és a gazdasági növekedés elósegitése, meg a mindezeket megalapozni kívánó sarkalatos törvények megalkotása vitára érdemes szak mai kérdések sorát veti a közgazdászok számára.

Emellett idén sem hiányzik majd a nemzetközi kitekintés a közgazdász vándorgyúlés témái közül és nemcsak a magyar soros elnökségi fél év tapasztalatainak értékelése okán.

Izgalmas időszakot él át ezekben a hónapokban az Európai Unió is. Görögország megmentése és az eurózóna egészének jövője, a tagállamok növekvő eladósodása, a közös gazdasági kormányzás bevezetése, nem utolsósorban pedig a 2014-2020-as idôzak költségvetési sarokszámainak a meghatározása okozza napjainkban a legtöbb fejtörést az európai döntéshozóknak, és ad bôven témát az elemzésre a közgazdászoknak.

Ezekhez a tartalmas szakmai vitákhoz, higgadt elemző beszélgetésekhez teremt fórumot a gazdaságpolitika és a gazdasági élet felső vezetốinek részvételével az Európa Kulturális Fớvárosa program keretében épült Kodály Központban megrendezendô 49. Közgazdász-vándorgyúlés.

Jelentkezés és további információ a társaság honlapján: http://www.mkt.hu 